PURQUERIO, LFV; MATTAR, GS; DUART, AM; MORAES, CC; ARAÚJO, HS; SANTOS, FF. 2019. Growth, yield, nutrient accumulation and export and thermal sum of Italian zucchini. Horticultura Brasileira 37: 221-227. DOI - http://dx.doi.org/10.1590/S0102-053620190214

\title{
Growth, yield, nutrient accumulation and export and thermal sum of Italian zucchini
}

\author{
Luis Felipe V Purquerio ${ }^{1} \mathbb{D}$; Gabriel S Mattar ${ }^{1} \mathbb{D}$; Adriana M Duart ${ }^{1} \mathbb{D}$; Carolina C de Moraes ${ }^{1} \mathbb{D}$; Humberto \\ S Araújo ${ }^{2} \mathbb{D}$; Fabrício Franco dos Santos ${ }^{1} \mathbb{D}$
}

${ }^{1}$ Instituto Agronômico (IAC), Campinas-SP, Brazil; felipe@iac.sp.gov.br; gabriel.mattar@uol.com.br; driamd@hotmail.com; carolcmoraes@ hotmail.com; fabricio_fr@yahoo.com.br; ${ }^{2}$ Polo Regional de Desenvolvimento Tecnológico dos Agronegócios Extremo Oeste, Andradina-SP, Brazil; humbertosaraujo@yahoo.com.br

\begin{abstract}
Studies on plant nutrition are essential for a correct fertilizer management, improving yield and quality of the product, and it also may contribute for an updating recommendation. The aim of this study was to evaluate growth, nutrient accumulation and export, thermal sum and yield of zucchini cultivar Corona F1. The experiment was carried out from August 8 to October 25, 2013, in Santo Antônio de Posse, São Paulo State. At the end of the research, 84 days after transplanting (DAT), we observed $95 \mathrm{~cm}$ average height with 36 leaves and $45.8 \mathrm{t} \mathrm{ha}^{-1}$ maximum yield. The nutrient accumulation, in g plant $^{-1}$, was: $\mathrm{N}(14.2)>\mathrm{K}(9.3)>\mathrm{Ca}(8.0)>\mathrm{Mg}(2.5)>\mathrm{S}(1.2)$ $>\mathrm{P}(0.9)$ and in $\mathrm{mg}$ plant $^{-1}$, $\mathrm{Mn}(49.3)>\mathrm{Fe}(34.9)>\mathrm{Zn}(19.6)>\mathrm{B}$ (16.4) $>\mathrm{Cu}(2.1)$ and export, in $\mathrm{kg} \mathrm{ha}^{-1}$, was $\mathrm{N}(94.9)>\mathrm{K}(44.1)>$ $\mathrm{Ca}(43.0)>\mathrm{Mg}(12.6)>\mathrm{S}(6.3)>\mathrm{P}(5.3)$, in $\mathrm{g} \mathrm{ha}^{-1}, \mathrm{Mn}(271.0)>$ $\mathrm{Fe}(159.2)>\mathrm{Zn}(105.6)>\mathrm{B}(82.8)>\mathrm{Cu}$ (11.9). The highest nutrient demand occurred between 40 and 50 DAT. Cultivar Corona F1 cycle was completed within 1.538 degree-days.
\end{abstract}

Keyword: Cucurbita pepo, growth, plant nutrition, horticulture, sustainability.

\section{RESUMO}

Crescimento, produtividade, acúmulo, exportação de nutrientes e soma térmica de abobrinha italiana

Pesquisas com nutrição de plantas são essenciais para a correta fertilização, melhorando produtividade e qualidade do produto, além de poder contribuir para a atualização da recomendação. $O$ objetivo do experimento foi avaliar o crescimento, acúmulo e exportação de nutrientes, soma térmica e produtividade da cultivar Corona F1. O trabalho foi conduzido no período de 2 de agosto a 25 de outubro de 2013, em Santo Antônio de Posse-SP. Ao final do experimento, 84 dias após o transplante (DAT), a altura média observada foi de $95 \mathrm{~cm}$ com 36 folhas e produtividade máxima obtida de $45,8 \mathrm{t} \mathrm{ha}^{-1}$. Concluiu-se que o acúmulo de nutrientes, em $g$ planta ${ }^{-1}$, foi de: $\mathrm{N}$ $(14,2)>\mathrm{K}(9,3)>\mathrm{Ca}(8,0)>\mathrm{Mg}(2,5)>\mathrm{S}(1,2)>\mathrm{P}(0,9)$ e em mg planta $^{-1}$, de $\mathrm{Mn}(49,3)>\mathrm{Fe}(34,9)>\mathrm{Zn}(19,6)>\mathrm{B}(16,4)>\mathrm{Cu}(2,1)$ e a exportação, em kg ha-1, foi de $\mathrm{N}(94,9)>\mathrm{K}(44,1)>\mathrm{Ca}(43,0)>$ $\operatorname{Mg}(12,6)>\mathrm{S}(6,3)>\mathrm{P}(5,3), \mathrm{em} \mathrm{g} \mathrm{ha}{ }^{-1}, \operatorname{Mn}(271,0)>\mathrm{Fe}(159,2)>$ $\mathrm{Zn}(105,6)>\mathrm{B}(82,8)>\mathrm{Cu}(11,9)$. A maior demanda por nutrientes ocorreu entre 40 e 50 DAT. A cultivar Corona F1 precisou de 1.538 graus dias para completar seu ciclo.

Palavras-chave: Cucurbita pepo, crescimento, nutrição de plantas, horticultura, sustentabilidade.

Received on April 18, 2018; accepted on January 10, 2019

Sol tudies on accumulation and export of nutrients show quantity and period of high gains of these nutrients as function of plant age, indicating when nutrient addition is necessary. Thus, these are important tools for management and fertilization of crops as also helping update existing recommendations (Furlani \& Purquerio, 2010; Purquerio et al., 2016; Moraes et al., 2018; Mattar et al., 2018).

Few studies on crop nutrition of Italian zucchini have been carried out. Most of them are about cucurbits of higher economic value, such as melon and watermelon (Pôrto et al., 2012). The found studies on zucchini evaluated nitrogen and potassium doses (Pôrto et al., 2012; Araújo et al., 2013, 2014; Costa et al., 2015; Andrean et al., 2017).

In addition to this lack of studies, the fertilizer recommendation in the state of São Paulo is the same for other five species (zucchini, pumpkin, winter squash, loofah and cucumber), with phenology and probable differentiated nutritional demand (Trani \& Raij, 1997). In this same recommendation, primary macronutrient content in fresh mass harvested for an average yield from 10 to $20 \mathrm{tha}^{-1}$ is presented. In the recommendation for the state of Minas Gerais, the expected yield is from 15 to $18 \mathrm{t} \mathrm{ha}^{-1}$ (Fontes, 1999). These yields are lower than the ones reached by hybrids available in the market these days, in several production systems. Results of yields verified in literature are very variable (29.9 to $71.4 \mathrm{t} \mathrm{ha}^{-1}$ ) (Strassburger et al., 2011b; Pôrto et al., 2012; Araújo et al., 2013; Costa et al., 2015) as function of growing cycle and harvest (unripe), superior to what was cited by Trani \& Raij (1997) though. Thus, higher mass production requires 
higher nutrient quantity.

For Italian zucchini, few reports on growth and gain of dry mass were found (Rouphael \& Colla, 2005; Strassburger et al., 2011a) and just one study on macronutrient accumulation throughout the growing cycle, for Novita hybrid (Araújo et al., 2001). In this study, which was published 15 years ago, the authors observed extraction, in $\mathrm{kg} \mathrm{ha}^{-1}$, of K (370.3), Ca (241.8), N (145), Mg (70.8), $\mathrm{P}$ (15.4), S (14.6) and export, in $\mathrm{kg} \mathrm{ha}^{-1}$ of K (121), N (96), Ca (11), P (15), $\mathrm{Mg}$ (9), $\mathrm{S}(5)$, at 64 days.

More studies on this crop are necessary, since nutritional misbalance, both because of lack or excess of nutrients, is a stressing factor for the plant (Furlani \& Purquerio, 2010) and it influences directly on production and final quality of product. Thus, data on accumulation and extraction of nutrients for new hybrids are essential to help refine existing fertilizer recommendations.

The use of methods for calculating thermal sum or degree days (GD) is based on premise that a plant needs a certain amount of energy to complete a given phenological phase or total cycle. These data allow to estimate the growing cycle duration and avoid periods in which the environment temperature may be limiting (Morais et al., 2010).

The aim of this study was to evaluate growth, nutrient accumulation and export, thermal sum and yield of Italian zucchini, cultivar Corona F1, grown during winter/spring.

\section{MATERIAL AND METHODS}

The experiment was carried out in the field, near the city of Santo Antônio de Posse (22 $34^{\prime} 08^{\prime \prime} \mathrm{S} 47^{\circ} 00^{\prime} 02^{\prime \prime} \mathrm{O}$, altitude $591 \mathrm{~m}$ ), from August (seedling transplanting) to October 25, 2013. According to Köppen, the climate is $\mathrm{Cwa}, 21.1^{\circ} \mathrm{C}$ average annual temperature and $1333.1 \mathrm{~mm}$ average annual rainfall (Cepagri, 2017). During the experimental period, average annual air temperature was $20.6^{\circ} \mathrm{C}$ and rainfall was $139.3 \mathrm{~mm}$. Average minimum and maximum temperatures ranged from $8^{\circ} \mathrm{C}$ to $32^{\circ} \mathrm{C}$ for the crop (NeSmith,
1997), considering the average $13.9^{\circ} \mathrm{C}$ and $27.4{ }^{\circ} \mathrm{C}$, respectively. The soil was classified as Red-Yellow Latosol (Embrapa, 2013), the chemical properties in 0 to $20 \mathrm{~cm}$ layer are: M.O.= $23 \mathrm{~g} \mathrm{dm}^{-3} ; \mathrm{pH}=5.8 ; \mathrm{P}=125 \mathrm{mg} \mathrm{dm}^{-3}$; $\mathrm{K}=4.0 \mathrm{mmol}_{\mathrm{c}} \mathrm{dm}^{-3} ; \mathrm{Ca}=36 \mathrm{mmol}_{\mathrm{c}} \mathrm{dm}^{-3}$; $\mathrm{Mg}=10 \mathrm{mmol}_{\mathrm{c}} \mathrm{dm}^{-3} ; \mathrm{H}+\mathrm{Al}=31 \mathrm{mmol}_{\mathrm{c}}$ $\mathrm{dm}^{-3}$; C.T.C. $=81.3 \mathrm{mmol}_{\mathrm{c}} \mathrm{dm}^{-3} \mathrm{~V}=62 \%$.

The seedlings of cultivar Corona F1 (Agristar) were sown in 200-cell trays, in a nursery, on July 19, 2013.

Planting fertilization was performed according to the result of soil analysis and the expertise of Agristar Company in the crop management. The authors used, in each linear 30-m seedbed, $1 \mathrm{~kg}$ simple superphosphate, 0.16 $\mathrm{kg}$ potassium chloride and $0.26 \mathrm{~kg}$ ammonium sulfate, totalizing $11.5 \mathrm{~kg}$ $\mathrm{N} \mathrm{ha}^{-1}, 39.9 \mathrm{~kg} \mathrm{P}_{2} \mathrm{O}_{5} \mathrm{ha}^{-1}$ and $20.6 \mathrm{~kg}$ $\mathrm{K}_{2} \mathrm{O} \mathrm{ha}^{-1}$.

Transplanting was done in $0.50-\mathrm{m}$ spacing between plants and $1.50 \mathrm{~m}$ between lines, in which each plant covered $0.75 \mathrm{~m}^{2}\left(13,333\right.$ plants ha $\left.\mathrm{a}^{-1}\right)$.

The experimental design was completely randomized with four replicates; the treatment's evaluations were performed on $0,14,28,42,56,70$ and 84 days after transplanting (DAT). Inside each block, three plants were evaluated for most traits and there were three border plants among the evaluated plants $\left(2.25-\mathrm{m}^{2}\right.$ useful plot). Border lines were also installed throughout the experiment. The total area was $270 \mathrm{~m}^{2}$ (360 plants).

The first evaluation (0 DAT) of mass and nutrient content in plant tissue was done at seedlings transplantation date, when the plant showed three definitive leaves.

In the first week, the authors applied $0.62 \mathrm{~kg} 13-40-13\left(\mathrm{~N}-\mathrm{P}_{2} \mathrm{O}_{5}-\mathrm{K}_{2} \mathrm{O}\right)$ per plot. From the second week up to the end of the crop cycle, 24 applications of 0.21 kg 25-05-25 were done, totalizing $4.9 \mathrm{~kg}$. We used $1.6 \mathrm{~kg}$ calcium nitrate splitted into five fertilizations from 30 DAT on. In total, we applied $349.7 \mathrm{~kg}$ $\mathrm{N} \mathrm{ha}^{-1}, 174.9 \mathrm{~kg} \mathrm{P}_{2} \mathrm{O}_{5} \mathrm{ha}^{-1}, 295.3 \mathrm{~kg}$ $\mathrm{K}_{2} \mathrm{O} \mathrm{ha}^{-1}$ and $66.6 \mathrm{~kg} \mathrm{Ca} \mathrm{ha}^{-1}$. Dripirrigation was carried out, with a dripping tube line per crop line. The soil was maintained at field capacity, monitored by tensiometers.

During the first 21 DAT, plants were kept under a low tunnel $(60 \mathrm{~cm})$, covered with white non-woven fabric (Fozpanos, $0.145 \mathrm{~g} \mathrm{~m}^{-2}$ ), in order to avoid pest attack, virus vectors. No incidence of viruses was verified during the crop cycle. Phytosanitary control was performed as required for aphid (Aphis gossypii), whitefly (Bemisia tabaci), pickleworm (Diaphania nitidalis), beetle (Diabrotica speciosa) and black cutworm (Agrotis ipsilon).

In each evaluation, plant height, number of leaves, fresh and dry mass of the plant (shoot area, fruits and root) and yield of marketable fruits were obtained. Due to different plant sizes throughout the growing cycle and in order to accumulate necessary dry mass for laboratorial analyses, in the first evaluation a hundred plants were collected, in the second evaluation ten plants and in the other evaluations three plants per replicate. Plants were harvested three times per week, collecting unripe fruits, within commercial standard (15 to $20-\mathrm{cm}$ length and mass close to $0.2 \mathrm{~kg}$ ).

To evaluate mass, plants were cut at soil level and divided into shoot area (leaves and stem) and fruits. Roots

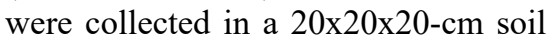
volume. Then, parts were weighed to determine fresh mass. After weighing, all the material was washed and packed in paper bags and taken to be dried in forced air circulation until constant mass $\left(60^{\circ} \mathrm{C}\right)$. After dried, the material was weighed and submitted to chemical analysis, in order to determine nutrient content in the plant tissue, according to the methodology proposed by Malavolta et al. (1997).

Due to the inexistence of a specific recommendation for zucchini leaf diagnosis, at 56 DAT, ripe and expanded leaves from the middle third of the plants were collected, aiming to compare with contents in the plant tissue for pumpkin of Trani \& Raij (1997).

Data were analysed using nonlinear three-parameter regression model, defined by the best statistical fit and coefficient of determination $\left(\mathrm{R}^{2}\right)$. SigmaPlot 12.5 was used for the analyses. 
Daily nutrient accumulation rates were obtained through subtraction between adjusted accumulation values of two consecutive days. The value of the previous day was subtracted from the value of the following day, determining the amount by which one exceeded the other. The inflection points of the adjusted curves corresponded to the moments in which the maximum rates of daily nutrient accumulation occurred. The periods of maximum accumulation of dry mass and nutrients were determined through the points of minimum and maximum curvature in the sigmoid models, calculated following the method cited by Venegas et al. (1998).

We calculated nutrient export by multiplying the values of accumulation in the fruit at 84 DAT by the yield calculated per hectare $(13,333$ plants $\left.\mathrm{ha}^{-1}\right)$. The amount of nutrients per ton of fruits was obtained dividing the total accumulation in the plant by the calculated yield.

Throughout the experiment, data were collected at minimum and maximum temperature $\left({ }^{\circ} \mathrm{C}\right)$ using a sensor, linked to a datalogger (CR1000, Campbell) installed close to the experimental area.

At the end of the cultivation, the thermal sum, in degree days (GD), was calculated based on the equation proposed by NesSmith (1997):

$$
\mathrm{GD}=\sum_{i=1}^{n}\left[\frac{(T \max +T \min )}{2}-T b\right]
$$

Where Tmax and Tmin were daily maximum and minimum air temperatures, $\mathrm{Tb}$ the temperature base for crop $\left(8^{\circ} \mathrm{C}\right)$, and $n$ number of days.
When Tmin was lower than $\mathrm{Tb}, \mathrm{Tb}$ was the value to be considered. When Tmax exceeded $32^{\circ} \mathrm{C}$, the formula [32-2(Tmax-32)] was used. $\mathrm{Tb}$ and temperature of $32^{\circ} \mathrm{C}$ was used, based on NeSmith (1997) methodology.

\section{RESULTS AND DISCUSSION}

For cultivar Corona F1, the authors observed yield of $45.8 \mathrm{tha}^{-1}$, value close to $40 \mathrm{t} \mathrm{ha}^{-1}$ observed by Araújo et al. (2001) for caserta type Novita (76 DAT). Results for yield of Italian zucchini verified in literature are very variable (29.9 to $71.4 \mathrm{t} \mathrm{ha}^{-1}$ ) (Strassburger et al., 2011b; Pôrto et al., 2012; Araújo et al., 2013; Costa et al., 2015) as function of growing period and harvest, since zucchini always is harvested unripe. However, these values are superior to the average yield 10 to $20 \mathrm{t} \mathrm{ha}^{-1}$, observed in recommendation for liming and fertilization for the state of São Paulo (Trani \& Raij, 1997).

Thermal sum totalized 1,538 degree days, value superior to the one verified by Araújo et al. (2001), 1,370 degree days. Nevertheless, Araújo et al. (2001) did not take into consideration the temperature conditions which were inferior to $\mathrm{Tb}$ or superior to $32^{\circ} \mathrm{C}$, thus the number of degree days might be superior. For cv. Caserta and Afrodite, Strassburger et al. (2011a) and Rouphael \& Colla (2005), respectively, verified that higher solar radiation availability, favored production and distribution of dry mass (MS), as well as all growth indexes, reinforcing data on studies which evaluated thermal sum.

Considering plant growth, up to 84 DAT, an increase in height $(95 \mathrm{~cm})$ and number of leaves (36) were noticed (Figure 1A). If necessary, to extrapolate the observed data, to detriment of DAT, phenological traits, such as number of leaves, can be used to monitor plant development and assist in nutrient distribution in seasons and regions of cultivation under different weather conditions which interfere with plant development (Moraes et al., 2016).

Plant grows slowly up to 27 DAT, intensifying the production of MS from that point until the end of growing cycle (Figure 1B). Maximum accumulation was estimated between 27 to 67 DAT, totalizing $320.5 \mathrm{~g} \mathrm{plant}^{-1}, 79 \%$ of total MS of $406.2 \mathrm{~g} \mathrm{plant}^{-1}$ at 84 DAT. Continuously growing in MS production of zucchini was also observed by Araújo et al. (2001), with total 229.6 g plant $^{-1}$ at 76 DAT and Strassburger et al.(2011a) for cv. Caserta, with $455.3 \mathrm{~g} \mathrm{plant}^{-1}$ at 68 DAT. Difference in plant dry mass is related to climatic conditions, as well as the management used and genotype.

MS accumulation curve for other cucurbits, such as melon, presents three well defined stages, the first is slow, the second is fast and in the third stage the accumulation rate decreases in relation to the second (Silva Júnior $e t$ al., 2006). Using Figure 1B, the authors could visualize that Italian zucchini also presented three accumulation stages.

For leaves and stems [shoot part (PA)], the authors verified maximum accumulation between 23 and 56 DAT with estimated value of $176.1 \mathrm{~g}$ plant $^{-1}$, representing $76 \%$ of the total accumulation $\left(232.1 \mathrm{~g} \mathrm{plant}^{-1}\right)$. After 70 DAT a stabilization tendency was verified. Strassburger et al. (2011a) observed continuous accumulation of dry mass in vegetative part of the plant,

Table 1. Extraction (EXT) and export (EXP) of nutrients by Italian zucchini Corona F1, ratio between export and extraction (REE) and quantity of nutrients extracted per ton of fruits (QNETF), 84 days after transplanting. Santo Antônio de Posse, Instituto Agronômico, 2013.

\begin{tabular}{|c|c|c|c|c|c|c|c|c|c|c|c|}
\hline & $\mathbf{N}$ & $\mathbf{P}$ & $\mathbf{K}$ & $\mathrm{Ca}$ & $\mathrm{Mg}$ & $\mathbf{S}$ & B & $\mathrm{Cu}$ & $\mathrm{Fe}$ & Mn & $\mathbf{Z n}$ \\
\hline & \multicolumn{6}{|c|}{$\left(\mathrm{kg} \mathrm{ha}^{-1}\right)$} & \multicolumn{5}{|c|}{$\left(\mathrm{g} \mathrm{ha}^{-1}\right)$} \\
\hline EXT & 189.5 & 12.0 & 124.1 & 106.2 & 33.0 & 15.4 & 219.2 & 28.2 & 465.8 & 657.5 & 262.0 \\
\hline \multirow[t]{2}{*}{ EXP } & 94.9 & 5.3 & 44.1 & 43.0 & 12.6 & 6.3 & 82.8 & 11.9 & 159.2 & 271.0 & 105.6 \\
\hline & \multicolumn{11}{|c|}{$(\%)$} \\
\hline \multirow[t]{2}{*}{ REE } & 50 & 44 & 36 & 40 & 38 & 41 & 38 & 42 & 34 & 41 & 40 \\
\hline & \multicolumn{6}{|c|}{$\left(\mathrm{kg} \mathrm{t}^{-1}\right)$} & \multicolumn{5}{|c|}{$\left(\mathrm{g} \mathrm{t}^{-1}\right)$} \\
\hline QNETF & 4.1 & 0.3 & 2.7 & 2.3 & 0.7 & 0.3 & 4.8 & 0.6 & 10.2 & 14.3 & 5.7 \\
\hline
\end{tabular}


$218.8 \mathrm{~g} \mathrm{plant}^{-1}$ at 68 DAT. Aumonde et al. (2011) explain the decrease in shoot mass accumulation, in annual crops (such as vegetables), considering fruits being strong drains and priority metabolic, compared to vegetative drains. Thus vegetative growth ceases or is significantly reduced in fruiting phase. Dry mass accumulation in fruits was accelerated from 40 to 70 DAT, with an estimated gain of $128.2 \mathrm{~g} \mathrm{plant}^{-1}$, or $77 \%$ of the total accumulation of 165.9 g plant ${ }^{-1}$.

At the end of the experiment, MS of PA represented $57 \%$ of total MS, whereas the fruits represented $41 \%$. Similar result was verified by Strassburger et al. (2011a) who found superior contribution of fruits of 52\% of total MS (236.5 $\left.\mathrm{g} \mathrm{plant}^{-1}\right)$. The result observed is not in accordance with literature, in which fruits show higher dry mass accumulation, since they represent the largest drains of photoassimilates, as verified for other cucurbits just like Vidigal et al. (2007) for Tetsukabuto hybrid pumpkin, Aguiar Neto et al. (2014) for melon and Almeida et al. (2014) for watermelon, with results between 60 to $84 \%$ of MS in fruits in relation to the total. This difference is due to the way Italian zucchini fruit is commercialized (unripe), making impossible the maximum accumulation of MS in this part of the plant. Strassburger et al. (2011a) also reported that fruit growth rate interfered little on the vegetative part; contradicting the tendency that greater growth rate of fruits reduces the growth rate of the vegetative part.

Root dry mass at the end of growing cycle was $6.1 \mathrm{~g} \mathrm{plant}^{-1}$. In relation to total dry mass, 406.2 g plant $^{-1}$, represented only $1.5 \%$, being little significant.

Comparing the results of leaf contents collected at 56 DAT, with contents suggested by Trani \& Raij (1997) for pumpkin, the authors observed that values of $\mathrm{N}\left(38.5 \mathrm{~g} \mathrm{~kg}^{-1}\right), \mathrm{Mg}\left(6.1 \mathrm{~g} \mathrm{~kg}^{-1}\right)$, $\mathrm{B}\left(46.3 \mathrm{mg} \mathrm{kg}^{-1}\right), \mathrm{Fe}\left(100.7 \mathrm{mg} \mathrm{kg}^{-1}\right)$ and $\mathrm{Zn}\left(59.9 \mathrm{mg} \mathrm{kg}^{-1}\right)$ are within indicated range. Contents of $\mathrm{S}\left(3.5 \mathrm{~g} \mathrm{~kg}^{-1}\right)$ and $\mathrm{Mn}$ (279.2 $\mathrm{mg} \mathrm{kg}^{-1}$ ) are above recommended values. Values of $\mathrm{K}\left(16.9 \mathrm{~g} \mathrm{~kg}^{-1}\right), \mathrm{P}(2.9$ $\left.\mathrm{g} \mathrm{kg}^{-1}\right)$ and $\mathrm{Cu}\left(5.3 \mathrm{mg} \mathrm{kg}^{-1}\right)$ are below. The difference verified for $\mathrm{S}, \mathrm{Mn}, \mathrm{K}$, $\mathrm{P}$ and $\mathrm{Cu}$ in leaf analysis was due to genetic traits, since reference values for comparison are values for pumpkin, due to the inexistence of data for zucchini. The authors highlight that despite the

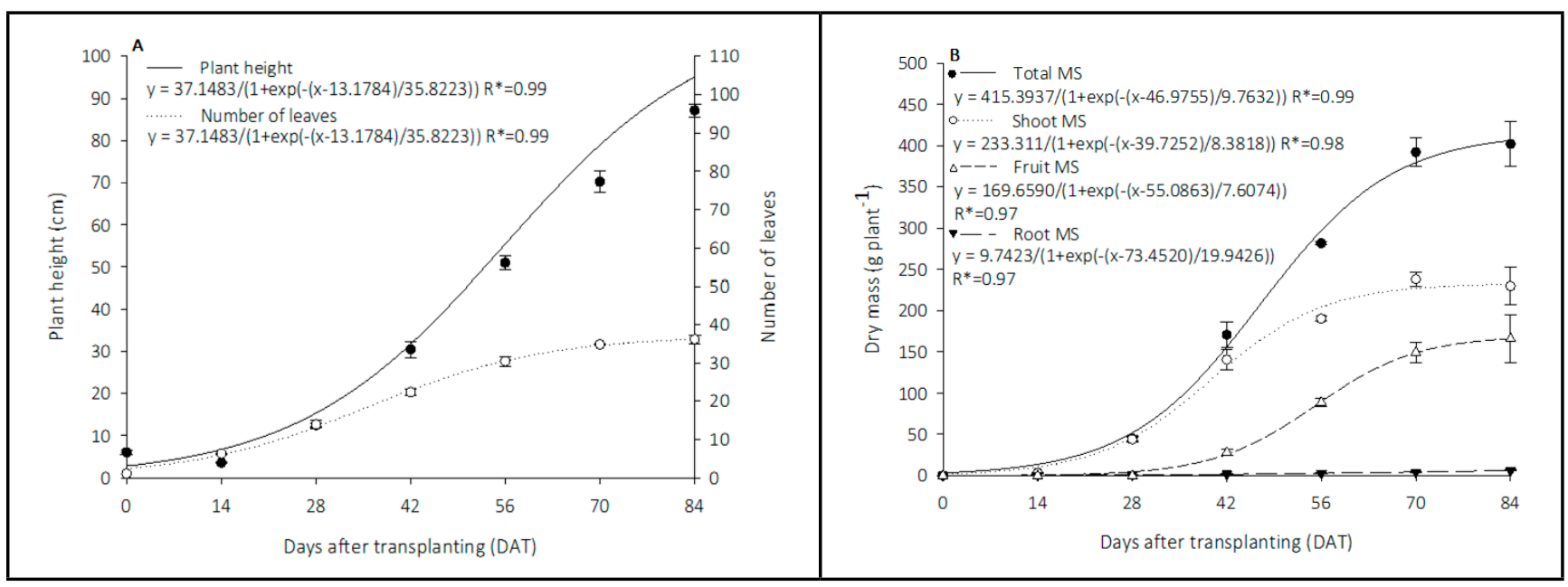

Figure 1. Plant height and number of leaves (A) and dry mass (B) of Italian zucchini Corona F1, in relation to days after transplantation. Average \pm standard error of four replicates. Santo Antônio de Posse, Instituto Agronômico, 2013.

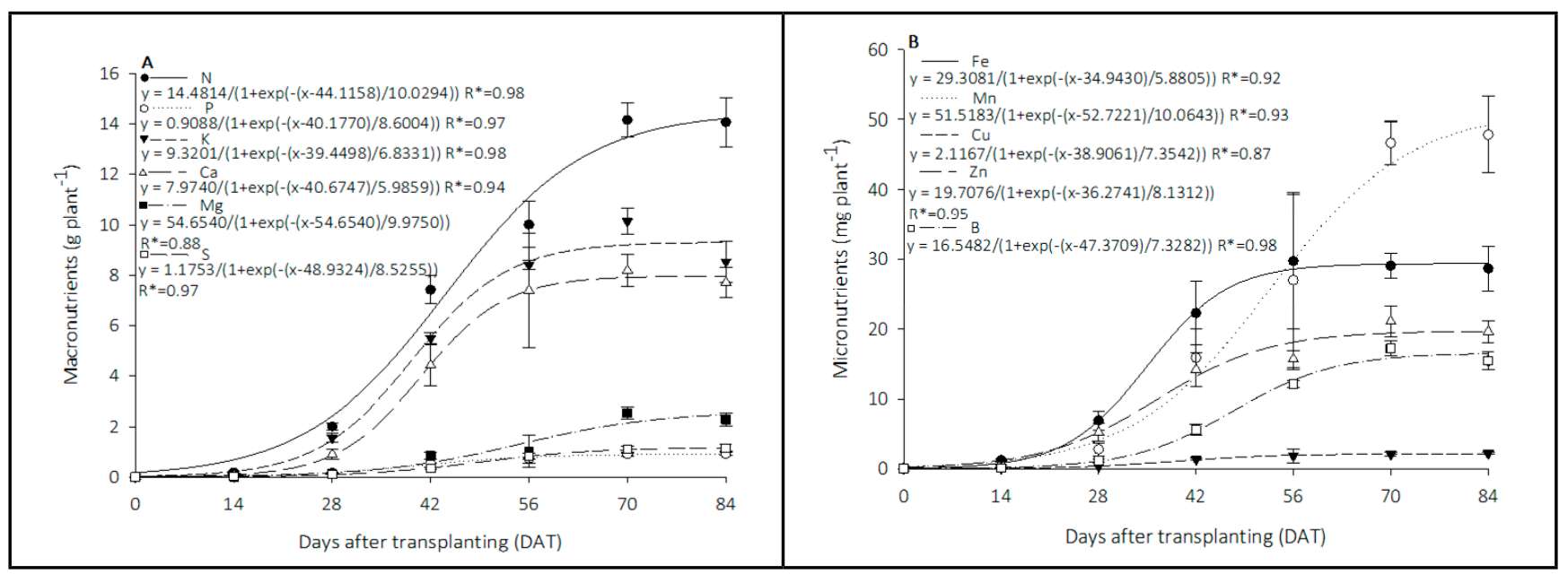

Figure 2. Accumulation of macro (A) and micronutrients (B) by Italian zucchini Corona F1, in relation to days after transplantation. Average \pm standard error of four replicates. Santo Antônio de Posse, Instituto Agronômico, 2013. 
differences observed in leaf analysis, no nutritional restriction during the experiment was noticed and the study estimated interesting production levels $\left(45.8 \mathrm{tha}^{-1}\right)$.

Plant nutrient accumulation was slow up to $28 \mathrm{DAT}$, from this date on, an increase for $\mathrm{N}, \mathrm{K}, \mathrm{Ca}, \mathrm{Fe}, \mathrm{Zn}$ and Mn was noticed, and for other nutrients this increase was verified after 42 DAT (Figure $2 \mathrm{~A}$ and B). For N, Mg and $\mathrm{Mn}$, an increasing accumulation up to the end of the experiment was noticed, for the rest of the nutrients a stabilization tendency near 70 DAT was verified, though. The same $\mathrm{N}$ pattern of accumulation was verified by Araújo et al. (2001); however, for P, $\mathrm{K}, \mathrm{Ca}$ and $\mathrm{Mg}$, the authors observed a decreasing accumulation from 76 DAT on. Gaitán et al. (2012) reported an increasing accumulation up to 60 DAT for $\mathrm{N}, \mathrm{P}, \mathrm{K}, \mathrm{Ca}$ and $\mathrm{Mg}$. We highlight that these mentioned authors evaluated accumulation of whole-plant, without differentiating parts as it was done in this study.

In cucurbits, an $\mathrm{N}$ increase, up to a certain limit, provide an increase in plant leaf area; thus, an effect on photoassimilate production can be noticed and, consequently, on fruit production (Pôrto et al., 2012). This nutrient was the most absorbed by the plant, and its value is estimated in 14.2 g plant ${ }^{-1}$ at 84 DAT, and maximum accumulation from 24 to 64 DAT with $11 \mathrm{~g} \mathrm{plant}^{-1}$, representing $77 \%$ of the total. This result is different from the ones reported by Araújo et al. (2001), in which potassium $\left(37 \mathrm{~g} \mathrm{plant}^{-1}\right)$ was the most accumulated nutrient, followed by $\mathrm{N}\left(14.5\right.$ g plant $\left.^{-1}\right)$ at 64 DAT.

Pwas the less absorbed macronutrient by the plant, $0.9 \mathrm{~g} \mathrm{plant}^{-1}$ at 84 DAT. Maximum accumulation was from 23 to 57 DAT, representing $76 \%$ of the total $\left(0.7 \mathrm{~g} \mathrm{plant}^{-1}\right)$. This nutrient is part of the chemical structure of essential compounds such as nucleic acids, phospholipids and coenzymes, and it is responsible for energy release process (Malavolta, 2006).

$\mathrm{K}$ controls cell turgidity, activates enzymes involved in the processes of respiration and photosynthesis and transport of carbohydrates. According to Araújo et al. (2014) and Andrean et al. (2017), an increase of doses of this nutrient, results in a higher content of potassium, $\mathrm{pH}$ and 'ratio' relation on Italian zucchini fruits, and also in an increase in number of male flowers. This macronutrient was the second most accumulated, $9.3 \mathrm{~g} \mathrm{plant}^{-1}$ at 84 DAT. Maximum accumulation occurred from 26 to 53 DAT, with 7 g plant $^{-1}$, representing $76 \%$ of the total.

$\mathrm{Ca}$, after $\mathrm{N}$ and $\mathrm{K}$, as well as for most of the cultivated plants (Malavolta, 2006) was the third most accumulated nutrient $\left(8 \mathrm{~g} \mathrm{plant}^{-1}\right)$. Maximum accumulation occurred between 29 to 53 DAT, corresponding to $76 \%$ of the total estimated value.

Maximum estimated accumulation of $\mathrm{Mg}$ was $2.5 \mathrm{~g} \mathrm{plant}^{-1}$ at 84 DAT. Higher uptake was verified between 35 and 75 DAT, equivalent to $80 \%$ of total value. This nutrient is a component of the chlorophyll molecule, besides being an enzymatic activator (Malavolta, 2006).

$\mathrm{S}$ is a structural component of proteins and coenzymes, taking part in vital processes, such as respiration and photosynthesis. Maximum accumulation was observed from 32 to 66 DAT, representing $77 \%$ of the total uptake, $1.2 \mathrm{~g} \mathrm{plant}^{-1}$.

For micronutrients, the accumulation sequence in mg plant ${ }^{-1}$ was $\mathrm{Mn}(49.3)>$ $\mathrm{Fe}(34.9)>\mathrm{Zn}(19.6)>\mathrm{B}(16.4)>\mathrm{Cu}$ (2.1). For Mn, the highest accumulation occurred between 33 and 73 DAT. This micronutrient differed from the others, as it increased up to the end of the cycle, without a stabilization tendency. The highest accumulation occurred for $\mathrm{Fe}$ from 23 to 47 DAT, $\mathrm{Zn}$ between 20 to 53 DAT, B from 33 to 62 DAT and $\mathrm{Cu}$ from 24 to 54 DAT. For all micronutrients, during higher accumulation, the authors observed values between 76 and $79 \%$ of total.

Daily nutrient accumulation rates allowed the elaboration of fertilization programs in function of time. In addition, nutrients over a different time period are necessary, making it possible to provide these nutrients when they are required and, thus, avoid lack of the nutrient or luxury consumption throughout the growing cycle (Furlani \& Purquerio, 2010). The authors noticed an increase in these rates up to a maximum value, maximum daily accumulation rate

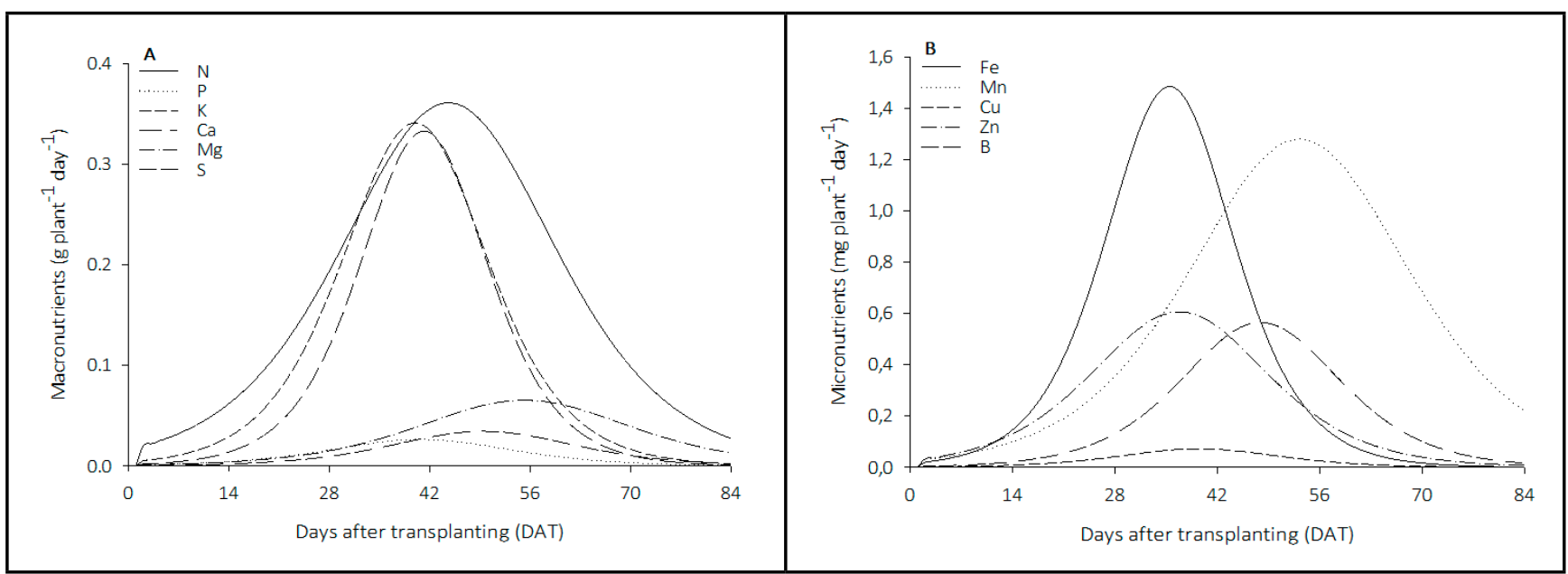

Figure 3. Daily accumulation rates of macro (A) and micronutrients (B) by Italian zucchini Corona F1, in relation to days after transplantation. Santo Antônio de Posse, Instituto Agronômico, 2013. 
(TMAD), with subsequent decrease until the end of the experiment. TMAD for macronutrients $\mathrm{N}, \mathrm{P}, \mathrm{K}, \mathrm{Ca}, \mathrm{Mg}$ and $\mathrm{S}$ were, respectively, $0.36 ; 0.03 ; 0.34$; $0.33 ; 0.06 ; 0.03$ g plant $^{-1}$, reached at 45 , 41, 40, 41, 55 and 49 DAT, respectively (Figure $3 \mathrm{~A}$ ). TMAD for $\mathrm{Fe}, \mathrm{Mn}, \mathrm{Cu}$, $\mathrm{Zn}$ and $\mathrm{B}$ were, respectively, 1.49; 1.28; $0.07 ; 0.6 ; 0.56 \mathrm{mg} \mathrm{plant}^{-1}$, reached at 35 , $53,39,37$ and 48 DAT (Figure 3 B).

Nutrients can be divided into two TMAD groups, earlier nutrient demand (close to 40 DAT), including N, P, K, Ca, $\mathrm{Fe}, \mathrm{Cu}$ and $\mathrm{Zn}$ and the second group, later nutrient demand (close to $50 \mathrm{DAT}$ ), including $\mathrm{Mg}, \mathrm{S}, \mathrm{Mn}, \mathrm{B}$.

Part of the extracted nutrients returns to soil via decomposition of the vegetal remains and part is removed via fruits (export). Thus, it is important to quantify and replenish, the nutrients accumulated in the harvested part of the plant. The order of extraction (EXT) and export (EXP) of the nutrients were the same, being presented in a decreasing order: $\mathrm{N}>\mathrm{K}>\mathrm{Ca}>\mathrm{Mg}>\mathrm{S}>\mathrm{P}>\mathrm{Mn}>\mathrm{Fe}$ $>\mathrm{Zn}>\mathrm{B}>\mathrm{Cu}$ (Table 1). Different sequences and amounts were observed by Araújo et al (2001), for EXT, in $\mathrm{kg}$ ha $^{-1}, \mathrm{~K}(370.3)>\mathrm{Ca}(241.8)>\mathrm{N}(145)$ $>\mathrm{Mg}(70.8)>\mathrm{P}(15.4)>\mathrm{S}(14.6)$ and for EXP, $\mathrm{K}(121)>\mathrm{N}(96)>\mathrm{P}(15)>$ $\mathrm{Ca}(11)>\mathrm{Mg}(9)>\mathrm{S}$ (5), with $40 \mathrm{t} \mathrm{ha}^{-1}$ yield. For hybrid Aline $60.7 \mathrm{t}$ fruits ha${ }^{1}$, Araújo et al. (2015) observed EXT, in $\mathrm{kg} \mathrm{ha}^{-1}$, of $\mathrm{K}(193,7)>\mathrm{Ca}(163,9)>$ $\mathrm{N}(154,5)>\operatorname{Mg}(51,9)>\mathrm{P}(25,4)>\mathrm{S}$ $(13,6)$ and EXP of $\mathrm{K}(107.95)>\mathrm{N}(91.7)$ $>\mathrm{P}(16.6)>\mathrm{Ca}(12.8)>\mathrm{Mg}(12.3)>\mathrm{S}$ (7.2). These authors observed that $\mathrm{K}$ was the nutrient extracted and exported in the greatest amount, to the detriment of $\mathrm{N}$ observed in this study. As seen for MS, this result is related to higher mass production of PA to detriment of fruits. For EXT (kg ha-1), Gaitán et al. (2012), verified higher value of $\mathrm{N}$ to detriment of $\mathrm{K}$, considering the sequence observed $\mathrm{Ca}(198.7)>\mathrm{N}(179.5)>\mathrm{Mg}(55)>$ $\mathrm{K}(36.4)>\mathrm{P}(17,8)$, corroborating the results in this study.

The ratio between extraction and export (REE) ranged from 34 to $44 \%$ for all nutrients with exception for $\mathrm{N}, 50 \%$, differing from what was verified by Araújo et al. (2001, 2015): P was much higher, 97 and $65 \%$, and $\mathrm{Ca}$ much lower,
5 and $8 \%$, respectively. In this study, although showing the smallest amount absorbed, $\mathrm{Cu}$ was, in percentage, the most exported nutrient (42\%).

The amount of nutrients extracted per ton of produced fruit (QNETFP) was $\mathrm{N}\left(4.1 \mathrm{~kg} \mathrm{t}^{-1}\right) \mathrm{P}\left(0.3 \mathrm{~kg} \mathrm{t}^{-1}\right)$ and $\mathrm{S}(0.3 \mathrm{~kg}$ $\left.\mathrm{t}^{-1}\right)$, close to values observed by Araújo et al. (2001), $\mathrm{N}\left(3.6 \mathrm{~kg} \mathrm{t}^{-1}\right), \mathrm{P}\left(0.4 \mathrm{~kg} \mathrm{t}^{-1}\right)$ and $\mathrm{S}\left(0.3 \mathrm{~kg} \mathrm{t}^{-1}\right)$, whereas $\mathrm{K}, \mathrm{Ca}$ and $\mathrm{Mg}$ were quite divergent, $2.7 \mathrm{~kg} \mathrm{t}^{-1}, 2.3 \mathrm{~kg} \mathrm{t}^{-1}$ and $0.7 \mathrm{~kg} \mathrm{t}^{-1}$, in this experiment, which was $9.3 \mathrm{~kg} \mathrm{t}^{-1}, 6 \mathrm{~kg} \mathrm{t}^{-1}, 2.3 \mathrm{~kg} \mathrm{t}^{-1}$ and 1.8 $\mathrm{kg} \mathrm{t}^{-1}$ respectively.

Comparing the results of extraction obtained with the recommendation for the state of São Paulo (Trani \& Raij, 1997), the authors observed the amount of $\mathrm{N}\left(189.5 \mathrm{~kg} \mathrm{ha}^{-1}\right)$ was in the upper limit of the proposed fertilizer range (140 to $190 \mathrm{~kg} \mathrm{ha}^{-1}$ ). This fact may be due to be calculated for an expected yield (10-20 t ha-1) which was inferior to the one observed in this study (45.8 $\left.\mathrm{t} \mathrm{ha} \mathrm{a}^{-1}\right)$. Studying doses of $\mathrm{N}$ in Italian zucchini, Costa et al. (2015) verified yield and dose close to the ones obtained in this experiment, $45.4 \mathrm{tha}^{-1}$ and $180 \mathrm{~kg}$ $\mathrm{N} \mathrm{ha}^{-1}$, respectively, whereas Pôrto et al. (2012) observed productive response lower $\left(29.9 \mathrm{t} \mathrm{ha}^{-1}\right)$ with much superior dose $\left(331 \mathrm{~kg} \mathrm{ha}^{-1}\right)$.

For $\mathrm{P}$, considering transformation of the amount observed in $\mathrm{P}_{2} \mathrm{O}_{5}$ (multiplying by 2.29) a total of $27.5 \mathrm{~kg} \mathrm{ha}^{-1}$ of $\mathrm{P}_{2} \mathrm{O}_{5}$ was found. This value is lower than the lowest limit of recommended fertilizer range, 200 to $400 \mathrm{~kg} \mathrm{ha}^{-1}$. This is related to the fact that $\mathrm{P}_{2} \mathrm{O}_{5}$ shows low dynamics in soil, and has a strong tendency to be fixed and to react with other components such as $\mathrm{Fe}, \mathrm{Al}$ and $\mathrm{Ca}$, among others, forming poorly soluble compounds. Thus its application assumes primarily the role of satisfying the soil requirement by adding several times higher amounts than those required by plants (Malavolta, 2006).

For $\mathrm{K}$, transformation into $\mathrm{K}_{2} \mathrm{O}$ was carried out (multiplying by 1.20 ). The authors observed that the plant required a total of $148.9 \mathrm{~kg} \mathrm{ha}^{-1}$ of $\mathrm{K}_{2} \mathrm{O}$, value lower than the range, 160 to $320 \mathrm{~kg}$ $\mathrm{ha}^{-1}$, (Trani \& Raij, 1997). The value verified in this study was close to the one found by Costa et al. (2015) $(137.8 \mathrm{~kg}$ $\mathrm{ha}^{-1}$ ), which allowed to obtain maximum yield $\left(23.8 \mathrm{tha}^{-1}\right)$. The authors highlight that nutrient use efficiency was not considered, and if this use efficiency was supposed to be considered, the amounts of these nutrients to be provided in fertilization would be higher.

The authors concluded that, for cultivar Corona F1, gain of dry mass was slow up to 27 DAT, intensifying until the end of the cycle, totaling $406.2 \mathrm{~g}$ plant $^{-1}$. At 84 DAT, the plant reached 95 $\mathrm{cm}$ average height, 36 leaves and yield of $45.8 \mathrm{t} \mathrm{ha}^{-1}$. The decreasing order of nutrient accumulation, in g plant $^{-1}$, was $\mathrm{N}(14.2)>\mathrm{K}(9.3)>\mathrm{Ca}(8.0)>\mathrm{Mg}(2.5)$ $>\mathrm{S}(1.2)>\mathrm{P}(0.9)$ and in mg plant ${ }^{-1}$, $\mathrm{Mn}(49.3)>\mathrm{Fe}(34.9)>\mathrm{Zn}(19.6)>\mathrm{B}$ $(16.4)>\mathrm{Cu}(2.1)$, whereas export in $\mathrm{kg}$ ha $^{-1}$ was N (94.9) $>\mathrm{K}(44.1)>\mathrm{Ca}(43)>$ $\mathrm{Mg}(12.6)>\mathrm{S}(6.3)>\mathrm{P}(5.3)$, in $\mathrm{g} \mathrm{ha}^{-1}$, $\mathrm{Mn}(271.0)>\mathrm{Fe}(159.2)>\mathrm{Zn}(105.6)$ $>\mathrm{B}(82.8)>\mathrm{Cu}$ (11.9). Thermal sum totalized 1,538 degree days.

\section{ACKNOWLEDGEMENTS}

To Coordination of Improvement of Higher Education Personnel (CAPES) for the scholarship for postgraduate students and Agristar do Brasil Ltda. for supporting this study.

\section{REFERENCES}

AGUIAR NETO, P; GRANGEIRO, LC; MENDES, MAS; COSTA, ND; CUNHA, APA. 2014. Crescimento e acúmulo de macronutrientes na cultura do melão em Baraúna-RN e Petrolina-PE. Revista Brasileira de Fruticultura 36: 556-567.

ALMEIDA, EIB; NÓBREGA, GN; CORRÊA, MCM; PINHEIRO, EAR; ARAÚJO, NA. 2014. Crescimento e marcha de absorção de micronutrientes para a cultivar de melancia Crimson Sweet. Revista Agroambiente 8: 74-80.

ANDREAN, AFBA; SALIM, CL; HACHMANN, TL; REZENDE, R; COSTA, AR. 2017. Nitrogen and potassium fertirrigation on yield characteristics of Italian zucchini in protected cultivation. African Journal of Agricultural Research 12: 200-207.

ARAÚJO, HS; CARDOSO, AII; EVANGELISTA, RM; TAKATA, WHS; SILVA, EG. 2014. Características físico-químicas de frutos de abobrinha-de-moita em função de doses de potássio em cobertura. Revista Colombiana de Ciencias Horticolas 8: 242-249.

ARAÚJO, HS; CARDOSO, AII; OLIVEIRA JÚNIOR, MX; MAGRO, FO. 2015. Teores 
e extração de macronutrientes em abobrinhade-moita em função de doses de potássio em cobertura. Revista Brasileira de Ciências Agrárias 10: 389-395.

ARAÚJO, HS; JUNIOR, MXO; MAGRO, FO; CARDOSO, AII. 2013. Doses de potássio em cobertura na produção de frutos de abobrinha italiana. Revista de Ciências Agrárias 36: 303-309.

ARAÚJO, WF; BOTREL, TA; CARMELLO, QAC; SAMPAIO, RA; VASCONCELOS, MRB. 2001. Marcha de absorção de nutrientes pela cultura da abobrinha conduzida sob fertirrigação. In: FOLEGATTI, MV; CASARINI, E; BLANCO, FF; BRASIL, RPC; RESENDE, RS (coord) Fertirrigação: flores, frutas e hortaliças. Guaíba: Agropecuária. p.67-77.

AUMONDE, TZ; PEDÓ, T; LOPES, NF; MORAES, DM; PEIL, RMN. 2011. Partição de matéria seca em plantas do híbrido mini melancia Smile enxertada e não enxertada. Revista Brasileira de Biociências 9: 387-391.

CEPAGRI - CENTRO DE PESQUISAS METEROLÓGICAS E CLIMÁTICAS APLICADAS À AGRICULTURA. 2017. Clima dos municipios paulistas. Available http://www.cpa.unicamp.br/outras informacoes/clima_muni_539.html. Accessed August 17, 2017.

COSTA, AR; REZENDE, R; FREITAS, PSL; GONCALVES, ACA; FRIZZONE, JA. 2015. A cultura da abobrinha italiana (Cucurbita pepo L.) em ambiente protegido utilizando fertirrigação nitrogenada e potássica. Irriga Botucatu 20: 105-127.

EMBRAPA. Centro Nacional de Pesquisa de Solos. 2013. Sistema Brasileiro de Classificação de Solos. Brasília: EMBRAPA 353p.

FONTES, PCR. 1999. Sugestões de adubação de hortaliças. In: RIBEIRO, AC; GUIMARÃES, PTG; ALVAREZ, VHV (org). Recomendações para o uso de corretivos e fertilizantes em Minas Gerais. Quinta aproximação. Viçosa: Comissão de fertilidade do solo do estado de
Minas Gerais. p. 171-174.

FURLANI, PR; PURQUERIO, LFV. 2010. Avanços e desafios na nutrição de hortaliças. In: MELLO PRADO, R; CECILIO FILHO, AB; CORREIA, MAR; PUGA, AP (org). Nutrição de plantas: diagnose foliar em hortaliças. Jaboticabal: FCAV. p.45-62.

GAITÁN, HAR; FUENTES, HR; ZACARIAS, CO; CONTRERAS, JAV; MALDONADO, AIL. 2012. Curvas de absorción de macronutrientes en calabacita italiana (Cucurbita pepo L.). Revista Fitotecnia Mexicana 35: 57-60.

MALAVOLTA, E; VITTI, GC; OLIVEIRA, SA. 1997. Avaliação do estado nutricional das plantas: princípios e aplicações. Piracicaba: POTAFOS. 319p.

MALAVOLTA E. 2006. Manual de nutrição mineral de plantas. São Paulo: Agronômica Ceres. 638p.

MATTAR, GS; MORAES, CC; MELETTI, LMM; PURQUERIO, LFV. 2018. Nutrient accumulation and export by passion fruit $\mathrm{cv}$. IAC 275. Revista Brasileira de Fruticultura 40: e-178.

MORAES, CC; ARAÚJO, HS; FACTOR, TL; PURQUERIO, LFV. 2016. Fenologia e acumulação de nutrientes por cebola de dia curto em semeadura direta. Revista de Ciências Agrárias 36: 281-290.

MORAES, CC; FACTOR, TL; ARAUJO, HS; PURQUERIO, LFV. 2018. Plant growth and nutrient accumulation in two tomato hybrids under tropical conditions. Australian Journal of Crop Science 12: 1419-1425.

MORAIS, ERC; MAIA, CE; NEGREIROS, MZ; ARAUJO JUNIOR, BB. 2010. Crescimento e produtividade do meloeiro Torreon influenciado pela cobertura do solo. Acta Scientiarum Agronomy 32: 301-308.

NESMITH, DS. 1997. Summer squash (Cucurbita pepo L.) leaf number as influenced by thermal time. Scientia Horticulturae. 68: 219-225.

PÔRTO, ML; PUIATTI, M; FONTES, PCR;
CECON, PR; ALVES, JC; ARRUDA, JA. 2012. Produtividade e acúmulo de nitrato nos frutos de abobrinha em função da adubação nitrogenada. Bragantia, 71: 190-195.

PURQUERIO, LFV; SANTOS, FFB; FACTOR, TL. 2016. Nutrient uptake by tomatoes 'Dominador' and 'Serato' grown in São Paulo State, Brazil. Acta Horticulturae, 1123: 35-40.

ROUPHAEL, Y; COLLA, G. 2005. Radiation and water use efficiencies of greenhouse zucchini squash in relation to different climate parameters. European Journal of Agronomy 23:183-194.

SILVA JUNIOR, MJ; MEDEIROS, JF; OLIVEIRA, FHT; DUTRA, I. 2006. Acúmulo de matéria seca e absorção de nutrientes pelo meloeiro "pele-de-sapo". Revista Brasileira de Engenharia Agrícola e Ambiental, 10: 364-368.

STRASSBURGER, AS; PEIL, RMN; FONSECA, LA; AUMONDE, TZ; MAUCH, CR. 2011a. Dinâmica de crescimento da abobrinha italiana em duas estações de cultivo. Acta Scientiarum Agronomy 33: 283-289.

STRASSBURGER, AS; PEIL, RMN; FONSECA, LA; AUMONDE, TZ; MAUCH. 2011b. Crescimento e produtividade da abobrinha italiana: efeito da concentração iônica da solução nutritiva. Ciências Agrárias 32: 553-564.

TRANI, PE; RAIJ, B. 1997. Hortaliças. In: RAIJ, B; CANTARELLA, H; QUAGGIO, JA; FURLANI, AMC (eds). Recomendações de adubação e calagem para o Estado de São Paulo. Campinas: Instituto Agronômico e Fundação de Apoio à Pesquisa Agrícola (FundAg). p.285

VENEGAS, JG; HARRIS, RS; SIMON, BA. 1998. A comprehensive equation for the pulmonary pressure-volume curve. Journal of Applied Physiology 84: 389-395.

VIDIGAL, SM; PACHECO, DD; FACION, CE. 2007. Crescimento e acúmulo de nutrientes pela abóbora híbrida tipo Tetsukabuto. Horticultura Brasileira 25: 375-380. 